\title{
A COMPARATIVE STUDY OF TECHNICAL EFFICIENCY OF ONION PRODUCING FARMS IN BANGLADESH
}

\author{
M. A. Baree, M. A. Rahman' ${ }^{1}$ M. H. A. Rashid ${ }^{2}$, M. N. Alam ${ }^{3}$ and S. Rahman ${ }^{4}$ \\ Department Crop Science \& Technology, University of Rajshahi, Rajshahi, Bangladesh
}

\begin{abstract}
This paper considers the comparative study to find out the farm-specific technical efficiency of the different categories of onion producing farms in Bangladesh. Cobb-Douglas stochastic frontier production function was used to estimate the parameters by using farm-level data. Some socio-economic factors like age, education, experience and plot size were taken into account in technical inefficiency effects model. The elasticity of output with respect to land and labour were 0.2077 and 0.0809 for small farm, 0.1076 and 0.0006 for medium farm and 0.0032 and 0.2406 for large farm respectively and with respect to seed, it was $0.0089,0.0015$ and -0.0008 for small, medium and large farms respectively and with respect to irrigation, it was $-0.0062,0.3014$ and 0.0721 for small, medium and large farms respectively and with respect to capital cost, it was $0.2089,-0.0072$ and 0.1376 for small, medium and large farms respectively. The coefficients of age were found to be expected negative sign in small and medium farms and it was positive sign for large farm. The coefficients of experience were significant with negative sign in small and medium farms. The coefficients of education were negative in small and medium farms and it was positive for large farm. The coefficients of plot size were insignificant with positive sign in small farm. The coefficients of plot size were found to be significant with negative value in medium and large farms. The farm-specific technical efficiencies of onion producing small, medium and large farms varied from 55 per cent to 99 per cent, 57 per cent to 99 per cent and 56 per cent to 99 per cent with a mean technical efficiency of 77 per cent, 87 per cent and 84 per cent respectively, which meant that without incurring any additional costs there was a scope to increase output per hectare of onion by 23 per cent, 13 per cent and 16 per cent for small, medium and large farms respectively through the efficient use of existing production technology.
\end{abstract}

Key Words: Onion, Stochastic frontier, Coefficient, Technical efficiency, Inefficiency of farm

\footnotetext{
1 Professor, Department of Agronomy \& Agricultural Extension, University of Rajshahi, Rajshahi, Bangladesh

2 Professor, Department of Agricultural Economics, Bangladesh Agricultural University, Mymensingh-2202, Bangladesh

${ }^{3}$ Professor, Department of Crop Science \& Technology, University of Rajshahi, Rajshahi, Bangladesh

4 Assistant Professor, Department of Animal Husbandry \& Veterinary Science, University of Rajshahi, Rajshahi, Bangladesh
} 


\section{INTRODUCTION}

Onion (Allium cepa L.) belongs to the family Amaryllidaceae or liliaceae (Hanelt 1990) and is one of the most important monocotyledonous, cross-pollinated cool season vegetable crops. It is known as a thermo-sensitive plant (Jones and Mann 1963). The probable origin of onion is in Iran, Pakistan, especially northern mountainous regions (Perseglove 1972). Onion is now widely cultivated in many areas of the world including topical and subtopical regions and it is the popular vegetable among most of the world's population and has a value for its pungent or mild flavours and form essential ingredients of the cooking of many regions. It is widely used as a condiment in preparation of soup, meat dishes, salads, sandwiches and is cooked alone as a vegetables. It is also processed as pickle, chutney and sauces and consumed in dehydrated form. Its pungency is due to the presence of the volatile oil (allyl propyl disulphide) (Yawalkar 1985). As medicinal properties (Vohora et al. 1974) onion reduces the cholesterol content in blood serum and thus is of valued against heart trouble. The effects of onion consumption in protection against cancer, coronary heart disease, diabetes as well as ageing, have been mainly attributed to organosulphur compounds, flavonoids, vitamins and some minerals (Kumari et al., 1995; Goldman et al., 1996; Teyssier et al., 2001). In Bangladesh it is cultivated over an area of land 51968 hectares with the total production of 272230 tons (BBS 2004). The average yield of onion bulbs per hectare is 6.83 tons (BBS 2005), which is not only low but uneconomical for commercial production as well. It requires an attention to identify the factors, which leads the low productivity of onion farms. Technical efficiency of onion farms is also an important factor in productivity growth. Technical efficiency is the ability to produce a given level of output with a minimum quantity of inputs under a given technology. In an economy where resources are scarce and opportunities for new technologies are lacking, technical efficiency studies will be able to show the possibilities to raise productivity by improving efficiency of farms without increasing the resource base or developing new technology. Estimates of the extent of inefficiency also help in deciding whether to improve efficiency or to develop new technologies to raise productivity of onion farms. The objectives of the study are to estimate the comparative farm-specific technical efficiency of small, medium and large farms of onion and identify some socio-economic factors, which influence the production efficiency of onion producing farms.

\section{MATERIALS AND METHODS}

Farrell (1957) suggested a method of measuring the technical efficiency of a farm in an industry by estimating the production function of firms, which are "fully-efficient" (i.e., a frontier production function). His production efficiency measure was able to overcome the problems associated with the traditional average productivity measures. Bravo-Ureta and Pinheiro (1993) also show an interest to those applications to examine the relationship between technical efficiencies and different socio-economic variables like age, education of farmer, farm size, and use of credit and extension services. The stochastic frontier model is theoretically reasonable and empirically competent method of measuring efficiency. This 
model permits random variation of the frontier across farms, and captures the effects of measurement error, other statistical noise and random shocks outside the farm's control.

\section{Data source and sampling}

The survey was conducted in small, medium and large farms of onion over the fifteen villages of Pabna district in Bangladesh during the period from January to June'2004. Stratified random sampling technique was used to stratify the farmers into the three strata (small farms having 0.02 to 1.01 hectares, medium farms having 1.02 to 3.03 hectares and large farms having above 3.03 hectares and considering proportionate random samples from each category of farms, a total of 225 sample farmers were selected. The required and relevant data on input-output coefficients, input-output prices and other related variables were also collected by the structured questionnaire through face-to-face interview method.

\section{Model specification}

A number of different methodologies to measure technical efficiency of which the frontier production function approach popularized by Aigner et al. (1977) is generally considered as an appropriate method. Farrell (1957) points out that the frontier production function is appropriate method for such analysis as it meets the theoretical definition of a production function. The stochastic frontier model is theoretically reasonable and empirically competent method of measuring efficiency. This model permits random variation of the frontier across farms, and captures the effects of measurement error, other statistical noise and random shocks outside the firm's control.

Cobb-Douglas production function specification provides an adequate representation of the production technology. It can be specified to estimate the level of technical efficiency. The model allows for technical inefficiency, which is occurred by the random shocks outside the control of producers can affect output. The specification of the Cobb-Douglas stochastic frontier production function model can be written as:

$$
\begin{aligned}
& \operatorname{InYi}=\beta_{0}+\sum_{i=1}^{5} \beta_{i} \operatorname{Inx} x_{i}+V_{i}-U_{i} \\
& \operatorname{In} Y_{i}=\beta_{0}+\beta_{1} \operatorname{In}\left(X_{1}\right)+\beta_{2} \operatorname{In}\left(X_{2}\right)+\beta_{3} \operatorname{In}\left(X_{3}\right)+\beta_{4} \operatorname{In}\left(X_{4}\right)+\beta_{5} \operatorname{In}\left(X_{5}\right)+V_{i}-U_{i}
\end{aligned}
$$

Where, $i$ indicates the $i$-th farmer, In represents the natural logarithm, $Y$ indicates per hectare output $(\mathrm{kg})$ and $X_{1}, X_{2}, X_{3}, X_{4}$ and $X_{5}$ stand for the land use cost / ha (Tk), quantity of labour/ha (man-days), amount of seed/ha (kg), irrigation hour/ha (hour) and capital cost/ha (Tk), respectively. The $V_{i}$ are considered to be independently and identically distributed random errors having $\mathrm{N}\left(0, \sigma_{\mathrm{v}}{ }^{2}\right)$ distribution that represents the random variations in output due to the factors which are not controllable of the producers like over flood, over rainfall, over drought, storm etc. and the $U_{i}$ represent the non-negative random variables which are called technical inefficiency effects, associated with the technical inefficiency of farms involved that may be controlled by the producers. 
Various socio-economic factors are responsible for the influence of farm-specific technical efficiencies or inefficiencies. The model of the technical inefficiency effects in the stochastic production frontier equation can be defined as:

$\mu_{i}=\delta_{0}+\delta_{1} Z_{1}+\delta_{2} Z_{2}+\delta_{3} Z_{3}+\delta_{4} Z_{4}$

Where $Z_{1}$ indicates the age of farm operator, $Z_{2}$ represents the experience of farm operator, $Z_{3}$ is the year of schooling of farmer and $Z_{4}$ denotes the farm size of onion. The $\beta$ and $\delta$ are unknown parameters to be estimated together with the variance parameters, which are expressed as:

$\sigma_{\mathrm{s}}^{2}=\sigma_{\mathrm{v}}^{2}+\sigma_{\mathrm{u}}^{2}$ and $\gamma=\sigma_{\mathrm{u}^{2}} / \sigma_{\mathrm{s}}^{2}$

Here, the $\gamma$-parameter contains the value between zero and one.

By the method of maximum likelihood, the parameters of the stochastic frontier production function model are estimated using the computer program, FRONTIER Version 4.1 (Coelli, 1996).

The technical inefficiency model for the inefficiency effects (2) can only be estimated if the inefficiency effects are stochastic. Hence, there is an interest in testing the null hypotheses that the inefficiency effects are not present:

$\mathrm{H}_{0}: \gamma=\delta_{0}=\delta_{1}=\delta_{2}=\delta_{3}=\delta_{4}=0$; and

The coefficients of the variables in the model for the inefficiency effects are zero,

$\mathrm{H}_{0}: \delta_{1}=\delta_{2}=\delta_{3}=\delta_{4}=0$.

These null hypotheses are tested by using the generalized likelihood-ratio statistics $\gamma$ that is defined by

$\gamma=-2 \operatorname{In}\left[\mathrm{L}\left(\mathrm{H}_{\mathrm{o}}\right) / \mathrm{L}\left(\mathrm{H}_{1}\right)\right]=-2\left[\operatorname{In}\left\{\mathrm{L}\left(\mathrm{H}_{\mathrm{o}}\right)\right\}-\operatorname{In}\left\{\mathrm{L}\left(\mathrm{H}_{1}\right)\right\}\right]$

Where $\mathrm{L}\left(\mathrm{H}_{0}\right)$ and $\mathrm{L}\left(\mathrm{H}_{1}\right)$ are the values of the likelihood function under the specifications of the null and alternative hypotheses $\mathrm{H}_{0}$ and $\mathrm{H}_{1}$, respectively. If the null hypothesis is true, then $\gamma$ has approximately a Chi-square (or a mixed Chi-square) distribution (Coelli, 1995).

Given the specifications of the stochastic frontier model (1) and (2), the technical efficiency of $\mathrm{i}$-th farmer can be shown to be equal to:

$\mathrm{TE}_{\mathrm{i}}=\exp \left(-\mathrm{U}_{\mathrm{i}}\right)$

Thus, the technical efficiency of a farmer is between zero and one and is inversely related to the inefficiency effect. The efficiencies are predicted using the predictor that is based on the conditional expectation of $\exp \left(\mathrm{U}_{\mathrm{i}}\right)$ (Battese and Coelli, 1993). 


\section{RESULTS AND DISCUSSION}

Maximum likelihood estimates of the stochastic frontier and technical inefficiency are represented in Table 1. The stochastic frontier model considers the variable inputs as land, labour, seed, irrigation and capital cost and socio-economic variables like age, experience, education and plot size are considered in the inefficiency model. The coefficient of land and labour were found to be positive and significant for small, medium and large farms. The elasticity of output with respect to land and labour were estimated to be positive values of 0.2077 and 0.0809 for small farm, 0.1076 and 0.0006 for medium farm and 0.0032 and 0.2406 for large farm respectively. Thereby it can be said that if the land area and number of labour are increased by one per cent, per hectare yield of onion is estimated to increase by 0.2077 per cent and 0.0809 per cent respectively in small farm, 0.1076 per cent and 0.0006 per cent respectively in medium farm and 0.0032 per cent and 0.2406 per cent respectively in large farm. The coefficient of seed was negative and insignificant for small and large farms and it was positive and significant for medium farm. The elasticity of output with respect to seed were $-0.0089,0.0015$ and -0.0008 for small, medium and large farms respectively. It indicates that if the amount of seed is increased by one per cent for small, medium and large farms, per hectare yield of onion is estimated to decrease by 0.0089 per cent in small farm and 0.0008 per cent in large farm and per hectare yield of onion is estimated to increase by 0.0015 per cent in medium farm. The coefficient of irrigation was observed to be negative and insignificant for small farm and it was positive and significant for medium and large farms. The elasticity of output with respect to irrigation was $-0.0062,0.3014$ and 0.0721 for small, medium and large farms respectively. These are meant that if the irrigation hour is increased by one per cent for small, medium and large farms, per hectare yield of onion is estimated to decrease by 0.0062 per cent in small farm and per hectare yield of onion is estimated to increase by 0.3014 per cent in medium farm and 0.0721 per cent in large farm. The coefficients of capital cost were positive and significant for small and large farms and it was negative and insignificant for medium farm. The elasticity of output with respect to capital cost was $0.2089,-0.0072$ and 0.1376 for small, medium and large farms respectively. Thus, it can be interpreted from the results that if the amount of capital cost is increased by one per cent for small, medium and large farms, per hectare yield of onion is estimated to increase by 0.2089 per cent in small farm and 0.1376 per cent in large farm and per hectare yield of onion is estimated to decrease by 0.0072 per cent in medium farm.

\section{Inefficiency effects}

In the technical inefficiency model, the estimated $\delta$-coefficients in Table 1 associated with the explanatory variables is worthy of particular discussion. The signs on the $\delta$-parameter in the inefficiency effect model are expected to be negative. The coefficients of age were found to be negative sign in small and medium farms and it was positive sign for large farm. The estimated coefficients with negative sign indicate that the technical inefficiency decreases if the age of farmer increases. The coefficient with positive sign for large farm means that the technical inefficiency effect increases with the increase in age of farmer. It can be interpreted that some old farmers may be weak mentally and physically due to 
their age and they are more conservative and for this, they are less willing to adopt new practices and risk in their farming operations. The coefficients of experience are found to be significant with negative sign in small, medium and large farms. It indicates that the technical inefficiency decreases if the experience of farmer increases. The coefficients of education were found to be negative sign in small and medium farms and it was positive sign for large farm.

Table 1. Maximum likelihood estimates for parameters of Cobb-Douglas stochastic frontier production function and technical inefficiency model for onion producing small, medium and large farms

\begin{tabular}{|c|c|c|c|c|c|c|c|}
\hline \multicolumn{2}{|c|}{ Farm categories } & \multicolumn{2}{|c|}{ Small farm } & \multicolumn{2}{|c|}{ Medium farm } & \multicolumn{2}{|c|}{ Large farm } \\
\hline Variables & Parameters & Coefficients & T-ratio & Coefficients & T-ratio & Coefficients & T-ratio \\
\hline \multicolumn{8}{|c|}{ Stochastic Frontier } \\
\hline Constant $\left(\mathrm{x}_{0}\right)$ & $\beta_{0}$ & $2.5585^{*}$ & 4.0701 & $3.1375^{*}$ & 3.0848 & $2.9077^{*}$ & 3.2615 \\
\hline Land $\left(\mathrm{x}_{1}\right)$ & $\beta_{1}$ & $0.2077^{*}$ & 2.2672 & $0.1076^{*}$ & 2.4471 & $0.0032^{*}$ & 3.8531 \\
\hline Labour $\left(\mathrm{x}_{2}\right)$ & $\beta_{2}$ & $0.0809 * *$ & 1.7005 & $0.0006^{*}$ & 3.2605 & $0.2406^{* *}$ & 1.9953 \\
\hline Seed $\left(x_{3}\right)$ & $\beta_{3}$ & -0.0089 & -0.0574 & $0.0015^{* *}$ & 1.7783 & -0.0008 & -0.8119 \\
\hline Irrigation $\left(x_{4}\right)$ & $\beta_{4}$ & -0.0062 & -0.5053 & $0.3014^{*}$ & 2.4117 & $0.0721^{*}$ & 2.0224 \\
\hline Capital cost $\left(\mathrm{x}_{5}\right)$ & $\beta_{5}$ & $0.2089^{*}$ & 3.3872 & -0.0072 & -1.2425 & $0.1376^{* *}$ & 1.7386 \\
\hline \multicolumn{8}{|c|}{ Inefficiency Model } \\
\hline Constant & $\delta_{0}$ & $0.1544^{*}$ & 3.2543 & -0.1889 & -0.6303 & -0.7330 & -0.0636 \\
\hline Age $\left(z_{1}\right)$ & $\delta_{1}$ & $-0.0042^{* *}$ & -1.6457 & -0.0003 & -0.0379 & 0.0008 & 0.6573 \\
\hline Experience $\left(\mathrm{z}_{2}\right)$ & $\delta_{2}$ & $-0.0007^{* *}$ & -1.7779 & $-0.0015^{*}$ & -2.5057 & $-0.0084^{*}$ & -2.1495 \\
\hline Education $\left(\mathrm{z}_{3}\right)$ & $\delta_{3}$ & $-0.0005^{* *}$ & -1.6526 & -0.0042 & -0.0058 & 0.0081 & 1.4437 \\
\hline Plot size $\left(\mathrm{z}_{4}\right)$ & $\delta_{4}$ & 0.0096 & 0.7832 & $-0.0076^{*}$ & -2.5043 & $-0.0004^{* *}$ & -1.7611 \\
\hline \multicolumn{8}{|c|}{ Variance Parameters } \\
\hline$\sigma_{\mathrm{s}}^{2}=\sigma_{\mathrm{v}}^{2}+\sigma_{\mathrm{u}}^{2}$ & & $0.676^{*}$ & 5.1158 & $0.8431^{*}$ & 4.5822 & $0.482^{*}$ & 5.3443 \\
\hline$\gamma=\sigma^{2} \mathrm{u} / \sigma_{\mathrm{s}}^{2}$ & & $0.8765^{* *}$ & 1.8208 & $0.4592^{* *}$ & 1.6777 & $0.6821^{* *}$ & 1.8461 \\
\hline \multicolumn{2}{|c|}{ Log-likelihood Function } & \multicolumn{2}{|c|}{-63.44} & \multicolumn{2}{|c|}{-86.23} & \multicolumn{2}{|c|}{-81.73} \\
\hline
\end{tabular}

Source: Own estimation, *Significant at $5 \%$ and **Significant at $10 \%$

The estimated coefficients with negative sign mean that the technical inefficiency decreases if the education of farmer increases. The coefficient of education with positive sign denotes that the technical inefficiency effect increases with the increase in education of farmer. The positive coefficient of education is unexpected but not entirely surprising. Since most of the educated farmers have alternative income sources and they do not completely rely on agriculture for their livelihood. If the farmers with more formal education have alternative income sources, or they are not attentive with farming practices and rely more on fixed labourer those are not educated, may have positive effect upon the inefficiency effects. The coefficients of plot size were insignificant but positive in small farm which represents that the technical inefficiency effect increases with the increase in plot size. Since the farmers with smaller operations may have alternative sources of 
income which are more important and hence put less effort into their farming operations and thereby may have positive effect of farm size upon the inefficiency effects. The coefficients of plot size were found to be significant with negative sign in medium and large farms. It denotes that the technical inefficiency decreases if the plot size increases. The positive and significant values of $\sigma^{2}$ and $\gamma$ showed that there were inefficiency effects in onion producing small, medium and large farms.

\section{Farm-specific technical efficiency}

Measuring the individual farm-specific technical efficiency than the average technical efficiency estimates is more useful for policy makers. Table 2 displays the frequency distribution of farm-specific technical efficiency estimates for onion producing small, medium and large farms. It is observed that 12 per cent, 24 per cent and 18.67 per cent of sample farmers were found to produce outputs which were very close to the maximum frontier outputs maintaining the efficiency level above 90 per cent and only 57.34 per cent, 33.34 per cent and 42.67 per cent of sample farms were observed to have obtained outputs lying on the efficiency level 0 per cent to 80 per cent while 30.66 per cent, 42.66 per cent and 38.66 per cent of sample farmers produced outputs following the efficiency level 80 per cent to 90 per cent.

Table 2. Distribution of technical efficiency of onion producing small farm

\begin{tabular}{|c|c|c|c|c|c|c|}
\hline \multirow{2}{*}{$\begin{array}{c}\text { Farm category } \\
\text { Efficiency }(\%)\end{array}$} & \multicolumn{2}{|c|}{ Small farm } & \multicolumn{2}{|c|}{ Medium farm } & \multicolumn{2}{|c|}{ Large farm } \\
\hline & $\begin{array}{l}\text { Number of } \\
\text { farms }\end{array}$ & $\begin{array}{l}\% \text { of } \\
\text { farms }\end{array}$ & $\begin{array}{l}\text { Number of } \\
\text { farms }\end{array}$ & $\begin{array}{l}\% \text { of } \\
\text { farms }\end{array}$ & $\begin{array}{l}\text { Number of } \\
\text { farms }\end{array}$ & $\%$ of farms \\
\hline $0-55$ & 0 & 0 & 0 & 0 & 0 & 0 \\
\hline $55-60$ & 5 & 6.67 & 2 & 2.67 & 3 & 4.00 \\
\hline $60-65$ & 6 & 8.00 & 3 & 4.00 & 4 & 5.33 \\
\hline $65-70$ & 9 & 12.00 & 5 & 6.67 & 6 & 8.00 \\
\hline $70-75$ & 9 & 12.00 & 7 & 9.33 & 8 & 10.67 \\
\hline $75-80$ & 14 & 18.67 & 8 & 10.67 & 11 & 14.67 \\
\hline $80-85$ & 13 & 17.33 & 14 & 18.66 & 17 & 22.66 \\
\hline $85-90$ & 10 & 13.33 & 18 & 24.00 & 12 & 16.00 \\
\hline $90-95$ & 5 & 6.67 & 10 & 13.33 & 8 & 10.67 \\
\hline $95-100$ & 4 & 5.33 & 8 & 10.67 & 6 & 8.00 \\
\hline Total number of farms & 75 & 100 & 75 & 100 & 75 & 100 \\
\hline Minimum & 55 & & 57 & & 56 & \\
\hline Maximum & 99 & & 99 & & 99 & \\
\hline Mean & 77 & & 87 & & 84 & \\
\hline Standard deviation & 12 & & 10 & & 11 & \\
\hline
\end{tabular}

Source: Own estimation 
The farm-specific technical efficiencies of onion producing small, medium and large farms varied from 55 per cent to 99 per cent with a mean technical efficiency of 77 per cent, 57 per cent to 99 per cent with a mean technical efficiency of 87 per cent and 56 per cent to 99 per cent with a mean technical efficiency of 84 per cent respectively. It can be interpreted from the result that on an average there appears to be 23 per cent, 13 per cent and 16 per cent technical inefficiencies among the sample farmers of onion farms. These imply that the output per hectare of onion farm can be increased on an average by 23 per cent, 13 per cent and 16 per cent in small, medium and large farms respectively through the efficient use of existing production technology without incurring any additional production costs.

\section{CONCLUSION}

The objectives of the study are to estimate the comparative farm-specific technical efficiency of onion producing small, medium and large farms and to identify some socioeconomic factors, which influence the production efficiency of onion farms. The required and relevant data on input-output coefficients, input-output prices and other related variables are collected from Santhia Upazila of Pabna district of Bangladesh during the period from January 2004 to July'2004 through face-to-face interview method. CobbDouglas stochastic frontier production function is used to estimate the parameters by using farm-level data. Some socio-economic factors like age, education, experience and plot size are taken into account in technical inefficiency effects model. The elasticity of output with respect to land and labour are 0.2077 and 0.0809 for small farm, 0.1076 and 0.0006 for medium farm and 0.0032 and 0.2406 for large farm respectively and with respect to seed, it is $-0.0089,0.0015$ and -0.0008 for small, medium and large farms respectively and with respect to irrigation, it is $-0.0062,0.3014$ and 0.0721 for small, medium and large farms respectively and with respect to capital cost, it is $0.2089,-0.0072$ and 0.1376 for small, medium and large farms respectively. The coefficients of age are found to be expected negative sign in small and medium farms and it is positive for large farm. The coefficients of experience are significant with negative sign in small and medium farms. The coefficients of education are negative in small and medium farms and it is positive for large farm. The coefficients of plot size are insignificant with positive sign in small farm. The coefficients of plot size are found to be significant with negative value in medium and large farms. The farm-specific technical efficiencies of onion producing small, medium and large farms vary from 55 per cent to 99 per cent, 57 per cent to 99 per cent and 56 per cent to 99 per cent with a mean technical efficiency of 77 per cent, 87 per cent and 84 per cent respectively. Among all categories of farms, small and large farms are found to be somewhat more relatively inefficient due to land fragmentation, less experience, illiteracy, etc., in the study area. There is a scope to increase output per hectare of onion by 23 per cent, 13 per cent and 16 per cent for small, medium and large farms respectively through the efficient use of existing level of agricultural inputs, the agricultural extension services and the available technology without incurring any additional costs. The findings of study indicate that there is a significant technical progress in all categories of onion farms. So, this study may be helpful for policy makers in this field to draw a strategic planning for increasing efficiency or reducing inefficiency of onion producing farms in Bangladesh. 


\section{REFERENCES}

Aigner, D., Lovell, C. A. K. and Schmidt, P. 1977. "Formulation and Estimation of Stochastic Frontier Production Function Models", J. Econ., 6, p. 21-37.

BBS, 2004. Statistical Yearbook of Bangladesh, Bangladesh Bureau of Statistics, Ministry of planning, Govt. of the People's Republic of Bangladesh, Dhaka, pp. 143.

BBS, 2005. Monthly (December) Statistical Bulletin. Bangladesh Bureau of Statistics. Statistics Division, Ministry of Planning, Govt. of the People's Republic of Bangladesh, pp. 54.

Battese, G. E. and Coelli, T. J. 1993. A Stochastic frontier Production Function Incorporating a model for Technical Inefficiency Effects, Working Papers in Econometrics and Applied Statistics, No. 69, Department of Econometrics, University of New England, Armidale, pp. 22.

Bravo-Ureta, B. E. and Pinheiro, A. E. 1993. Efficiency Analysis of Developing Country Agriculture: A Review of the Frontier Function Literature; Agricultural and Resource Economics Review, 22, 88-101.

Coelli, T. J. 1995. A Monte Carlo Analysis of the Stochastic Frontier Production Function, J. Product. Analy., 6: 247-268

Coelli, T. J. 1996. A Guide to Frontier Version 4.1: A Computer Program for Stochastic Frontier Production and Cost Function Estimation, CEPA Working Paper 7/96, Centre for Efficiency and Productivity Analysis, University of New England, Armidale, pp. 3-20.

Farrell, M. J. 1957. The measurement of productive efficiency, J. Royal Stat. Soc., Series A, 120: 253-290.

Goldman, I. L., Kopelberg, M., Debaene, J. E. and Schwartz, B. S. 1996. Antiplatelet activity in onion (Allium cepa) is sulfur dependent. Thromb. Haemost., 76(3): 450-452.

Hanelt, P. 1990. “Taxonomy, Evolution and History”, In: Rabinowitch, H. D. and J. L. Brewster (eds), Onions and Allied Crops, CRC Press, Boca Raton, Florida, 1: 1-26.

Jones, H. A. and Mann, L. K. 1963. “Onion and Their Allies”, Leonard Hill, London, 169 p.

Kumari, K., Mathew, B. C., Augusti, K. T. 1995. Antidiabetic and hypolipidemic effects of S-methyl cysteine sulfoxide isolated from Allium cepa Linn. Indian J Biochem. Biophys., Feb; 32(1): 49-54.

Perseglove, J. W. 1972. “Tropical Crops: Monocotyledons 1 and 2", Longman Group Limited, London, 32-50.

Teyssier, C., Amiot, M. J., Mondy, N., Auger, J., Kahane, R. and Siess, M. H. 2001. Effect of onionconsumption by rats on hepatic drug-metabolizing enzymes. Food and Chemical Toxicology, 39(10): 981-7.

Vohora, S. B., Rizman, M. and Khan, J. A. 1974. Medicinal Use of Comon Indian Vegetables Planta Medica, 23(4): 381-393.

Yawalker, K. S. 1985. "Vegetable Crops in India”, Agri-Horticultural Publishing House, Nagpur, 288-563. 